\title{
Households' characteristics and perceptions of weather variability impact on rice yield: empirical analysis of small scale farmers in Tanzania
}

\author{
Peter David Kulyakwave ${ }^{1,2,3}$ (D) Xu Shiwei ${ }^{1 * 2}$ Wen Yu ${ }^{1,2}$ \\ ${ }^{1}$ Agricultural Information Institute, Chinese Academy of Agricultural Sciences, Beijing, China. E-mail: xushiwei@caas.cn. \\ ${ }^{*}$ Corresponding author. \\ ${ }^{2}$ Key Laboratory of Digital Agricultural Early-Warning Technology, Ministry of Agriculture, Beijing, China. \\ ${ }^{3}$ Department of Research, Training, and Market Development, Tanzania National Service Headquarters, Box 1694, Dar Es Salaam, Tanzania.
}

ABSTRACT: Rice farming is characterized by various factors including environmental and non-environmental factors. The current paper analyses the influence of households'characteristics, and perceptions of weather variability on rice yield. Authors used primary data collected from small-scale rice farmers in the Mbeya region of Tanzania. Garret technique and Stata software were used for data analyses. Results confirmed that farmer's education, marital status, gender, and land ownership have a positive influence on rice yield. Thus, for every $1 \%$ increase in each variable increases rice yield by 14\%, 98\%, 26\%, and 21\% respectively. Owing to empirical results on farmers 'perceptions, it is confirmed that if the drought period increased by $1 \%$, would on average reduce rice yield by 20\%. The majority of farmers (70\%) have perceived that drought period reduced their rice yield. In addition, farmers' used averagely less quantity of rice seeds which have impaired their rice yields. If farmers increased the seed quantity by $1 \%$, rice yields would increase by $17 \%$. Our findings also revealed that the previous market price has positive association with the next seasons' rice yield. Therefore, our study concluded that among households' variables and their perceptions have positive implications on rice yield; however, with the empirical analyses other variables were insignificant due to multicollinearity effects. Authors recommended to the government and other responsible organizations to capitalize on irrigation infrastructures, agricultural extension and technological services to restraint the enduring food insecurity coercions in Tanzania.

Key words: rice yield, weather, perceptions, empirical analysis, Tanzania.

Características dos agregados familiares e percepções da variabilidade climática na produção de arroz: análise empírica de pequenos agricultores na Tanzânia

RESUMO: O presente trabalho analisa a influência das características das famílias e as percepções da variabilidade climática na produção de arroz. Os autores usaram dados primários coletados de pequenos produtores de arroz na região de Mbeya, na Tanzânia. A técnica de Garret e o software Stata foram utilizados para análise de dados. Os resultados confirmam que a educação do agricultor, estado civil, gênero e propriedade da terra têm uma influência positiva no rendimento do arroz. Assim, para cada aumento de $1 \%$ em cada variável aumenta a produção de arroz em 14\%, 98\%, 26\% e 21\%, respectivamente. Devido aos resultados empíricos sobre as percepções dos agricultores confirma-se que se o periodo de seca aumentar 1\%, reduziria em média a produção de arroz em 20\%. A maioria dos agricultores (70\%) percebeu o periodo de seca para reduzir o rendimento do arroz. Além disso, os agricultores usam uma quantidade média menor de sementes de arroz que prejudicaram o rendimento do arroz. Se os agricultores aumentarem a quantidade de sementes em $1 \%$, o rendimento do arroz aumentará em 17\%. Nossas descobertas também revelaram que o preço de mercado anterior tem associação positiva com a produção de arroz das próximas safras. Portanto, nosso estudo conclui que entre as variáveis das familias e suas percepções apresentam uma implicação positiva na produção de arroz, no entanto, com as análises empíricas, outras variáveis foram insignificantes devido aos efeitos de multicolinearidade. Os autores recomendaram ao governo e a outras organizações responsáveis que capitalizassem as infraestruturas de irrigação, a extensão agrícola e os serviços tecnológicos para conter as coercões duradouras de insegurança alimentar na Tanzânia.

Palavras-chave: rendimento de arroz, clima, percepções, análise empírica, Tanzânia.

\section{INTRODUCTION}

Rice is among the staple cereal foods for the world's developing countries (MUTHAYYA, SUGIMOTO, MONTGOMERY, \& AND MABERLY, 2014). Currently, it is a staple food for almost over $60 \%$ of the world's population (CHIDI, ANOZIE, \& CHINAZA, 2015; MOHANTY, WASSMANN, NELSON, MOYA, \& JAGADISH, 2013). In Tanzania, rice is ranked second to maize in term of both production and consumption in rural and cities (THERKILDSEN \& THERKILDSEN, 2011). Current statistics attested that among the leading SubSaharan Africa countries in rice production Tanzania is ranked second after Madagascar (FEWSNET, 2016). Meanwhile, rice contributes approximately up to 3 per cent of the country's Gross Domestic Product and its share to world rice is 0.4 cent. The country is in fourth and within $22^{\text {nd }}$ in both Africa and World in terms of rice production statistics (TIGCHELAAR, BATTISTI, NAYLOR, \& RAY, 2018). Generally, rice production is dominated by small-scale rural placed 
farmers with an average of less than 2 ha per person (MSANGYA et al., 2016). Owing to that it is now considered vital for both human consumption and economic growth. Additionally, farmers face myriads of challenges including low skilled labors, deprived technology and extension services, high cost of inputs, and unpredictability of weather variations (MWATAWALA, 2016; NKUBA et al., 2016).

Recent studies have confirmed that the major key players in Tanzania's rice production are small scale-holders (NKUBA et al., 2016; WILSON \& LEWIS, 2015). Small-scale rice producers' share account to above $90 \%$ and produce only for subsistence rather than for commercial drives. Likewise, more than $30 \%$ of rice outputs are for families' consumption and the remained portion is commercially traded. Due to numerous challenges facing rice farmers in Tanzania the country's rice yield stand at 1.5 tonnes per ha far below 2.5 and 4.4 tonnes per ha of Africa and Asia respectively (NKUBA et al., 2016;). Considerably, the major reasons for such deviations are the dependence on rain-fed rice, poor technologies adoption, and poor governance (VAN ITTERSUM et al., 2016). However, if Tanzania could fully exploit her available rice potentials through enhanced irrigation technology, improved seeds, and the available profitable land could go beyond the world rice yield potential (THERKILDSEN \& THERKILDSEN, 2011). As is purported in previous research, many challenges facing smallholder's farmers have already advocated including impacts of climate change on crop yields in Tanzania. The studies which have already commented on the negative impacts of meteorological changes to rice production in Tanzania includes MKONDA \& HE, 2017; MUGULA AND MKUNA, 2016; MTONGORI, STORDAL, BENESTAD, MOURICE, \& JUSTINO, 2015; ROWHANI, LOBELL, LINDERMAN, \& RAMANKUTTY, 2011. Other recent studies are based on marketing and general management across rice production chain (ASHC, 2015; MKONDA, 2017; NKUBA et al., 2016). For example, a study by Mkonda relied on exploring the relationship between local farmers' perceptions for meteorological variables with time series weather data (MKONDA, 2017). They reported an existing significant relationship between the two; nevertheless, no econometric relationships were established.

Another worthy study by MWATAWALA et al. (2016) conducted in Southern Highland regions centred on examining the contribution of rice yield to households' income and the challenges facing small-scale farmers in the region. Their findings attested that rice was the main contributor $(46 \%)$ of family's income in the region. Also using multilinear regression, the authors considered other factors hindering rice production in Mbarali district than weather. Furthermore, a study by ROWHANI et al. (2011) provided a base to relate yields with weather variations in Tanzania. Although, in their study, relationships were well established by empirical models house-holds characteristics and their perceptions of weather attributes were not encompassed. So, this current study aimed to fill the prevailing knowledge gap by scrutinizing how small-scale farmers' attributes and their perceptions of weather variations are related to rice yields. Therefore, the objectives of this research included characterizing rice farmer's house-holds attributes with reference to rice yields, analyse the house-holds perceptions of weather variability, and to link households' traits, and their perceptions with rice yields in the study region.

\section{MATERIALS AND METHODS}

\section{Profile of the study area}

Mbeya region is located in the Southern Highlands of Tanzania. It is situated between latitudes 70 and 9031 ' to the south of equator and longitude 320 and 350 east of Greenwich. The region is among the leading regions in term of agricultural outputs in Tanzania (MAKOI, 2016). The region has the tropical climate which errand cereal productions. Mbarali and Kyela districts are among the important districts where rice is cultivated. Mbarali is bordered with Rural Iringa district in the north, to the west by Chunya district, and Mbeya rural district to the South. It receives from $300 \mathrm{~mm}-900 \mathrm{~mm}$ average rainfall per year which starts from December to April as compared to $350 \mathrm{~mm}-800 \mathrm{~mm}$ for Kyela district. Kyela district is located to the South of Mbeya region, bordered with Makete to the east, Ileje district in the west, and south by the Republic of Malawi.

\section{Data collection and sampling}

Two important rice-producing districts were purposely selected for the survey within the region. Furthermore, 122 and 118 rice farming households were randomly selected from Mbarali and Kyela districts respectively constituting a total of 240 respondents. In addition, a face to face interview was conducted using structured questionnaires from February to March 2018. The interview focused on general rice fields' activities led by households and their perceptions on the changing weather variables. 
To make sure the interviews were performed up to standards the authors prepared and train research assistants who could well understand and interpret the questionnaires to respective respondents.

\section{Socio-economic attributes of the households Households' characteristics}

Age: Descriptive statistics showed that average respondents' age was 45 years. The majority $(52 \%)$ of the households' head had ages below the average. Comparing rice yields with age, households' head with less or equal to the average age reaped higher yields $3396 \mathrm{Kg}$ per ha as shown in table 1 . The study assessed age so as to find out the proportion of farmers with different age groups involved in farming practices. Descriptive statistics in table 1 showed that average respondents' age was 45 years. Majority $(52 \%)$ of the households' head had ages below the average. In comparison to rice yields, households' head with age less or equal to the average age reaped higher yields $3396 \mathrm{Kg}$ per ha as shown in table 1 . This indicated that most rice farmers in the study area are young, active, and fall within the productive group, thus, favour their participation in rice production. Our finding concurs with (TSEGA, DAWIT, \& SHIRTORI, 2013) in Ethiopia, and also (AKPAN et al, 2015) in Nigeria who commented that majority youth with ages between 45-50 years are engaged in crops production.

Gender: Majority (85\%) of the households' head were males. Based on rice yields, even though males headed family exceeded females but they earned less rice yield about $3504 \mathrm{Kg}$ per ha compared to $3720 \mathrm{Kg}$ per ha for females. The main reason could be that most males have off-farm jobs and less attention is paid to the rice fields.

Education: Education offers essential skills for an individual to master his environment. Fifty-six percent of the respondents had formal (from primary to university) education. This education is also reflected in the yield as those with formal education had higher yields (3552 Kg per ha) as opposed to $3480 \mathrm{Kg}$ per ha obtained by uneducated households. This finding is supported by (KIM et al., 2017) as pointed that adequate education could help farmers in technology acceptance and accessing extension services. Fifty-six per cent of the respondents had from primary to university education (Literacy) and they were able to acquire higher yields (3552 Kg per ha) as compared to $3480 \mathrm{Kg}$ per ha obtained by households with less education.

Marital status: Majority of the respondents (96\%) were married. On average, married couples earned about $3624 \mathrm{Kg}$ per ha as compared to $1344 \mathrm{Kg}$ per ha gained by non-married respondents. This showed that marital status has advantages toward rice yields as it can help to restrain the labor size problem. OTEKHILE \& VERTER (2017) reported similar findings in Nigeria; however, they added that spouses provide assistance to most agricultural activities in Nigeria.

Labor size: Further scrutiny has shown that the average labor size per household was 2.7; meanwhile, $51 \%$ of the households had less labor size than the average. However, it was precisely implausible that households with less average labor size reaped higher rice yield (3600 Kg per ha) contrary to largely sized labor with $3528 \mathrm{Kg}$ per ha. This could be due to the constituent of members who are engaged to other non-farming activities. For example, it is very obvious that most youths aged from 18-25 years do not like farming activities in Tanzania. Similar finding was observed by KIM et al. (2017); MANGO et al. (2018) as they commented that majority households had from 6-10 members but only a small number participated in farming activities in Nigeria and South Africa, respectively.

Land ownership: Analysis showed that the majority (89\%) of the respondents own land. Owing to the ownership, farmers were able to earn higher yields $3552 \mathrm{Kg}$ per ha than those without land. Our findings go in line with the statistics from the Tanzania National Bureau of Statistics (NBS) as is revealed that in the rural areas of Tanzania about $85 \%$ of the population owns land or farm as compared to $41.2 \%$ in the urban areas (NBS, 2014).

Farm size: The average farm size allocated to rice production by respondent was 2.7 ha; however, the majority $(64 \%)$ of the respondents allocated less than the reported average farm size. The computed descriptive analyses illustrated those respondents who allocated less sized plots to rice farming earned higher yields than the larger farm size. The fallouts exhibited an inverse relationship between farm size and rice yield. The reasons contributed to high inputs costs, weather impacts, management stresses, and also inefficient resources allocation.

\section{Weather characteristics}

Drought and Floods: Among the farmers, $61 \%$ confirmed to experience drought in recent years. In addition, $70 \%$ of respondents attested to experience extreme floods in recent seasons. According to the analysis, extreme floods event have affected respondents to earn fewer yields $(3840 \mathrm{Kg}$ per ha) as compared to $4104 \mathrm{Kg}$ per ha obtained by those who did not experience floods in their field. This adds that weather variations impair crops revenue and 
Table 1 - Descriptive statistics and definition of variable with rice yield.

\begin{tabular}{|c|c|c|c|c|c|c|}
\hline Variable & Variable definition & Group & Obsn & $\%$ & $\begin{array}{c}\text { Mean } \\
\text { Yield(Kg/ha) }\end{array}$ & $\begin{array}{l}\text { Wilcox } \\
\text { on test }\end{array}$ \\
\hline \multirow[b]{2}{*}{ age } & \multirow{2}{*}{$\begin{array}{c}\text { Dummy variable, age }=1 \text { as household head's age is less } \\
\text { or equal to } 45 \text { years old; or age }=0 \text { if age is greater than } \\
45 \text { years old }\end{array}$} & 0 & 114 & 48 & 3336 & \multirow[t]{2}{*}{0.438} \\
\hline & & 1 & 126 & 52 & 3396 & \\
\hline \multirow{2}{*}{ gender } & \multirow{2}{*}{$\begin{array}{l}\text { Dummy variable, gender }=1 \text { as household head's gender } \\
\text { is male, or gender is }=0 \text { as female }\end{array}$} & 0 & 35 & 15 & 3720 & \multirow[t]{2}{*}{0.464} \\
\hline & & 1 & 205 & 85 & 3504 & \\
\hline \multirow[b]{2}{*}{ edu } & \multirow{2}{*}{$\begin{array}{c}\text { Dummy variable, edu }=1 \text {, as household head's } \\
\text { education is literate(from } 7 \text { years and above), or } \\
\text { illiterate (less than } 7 \text { years) education=0 }\end{array}$} & 1 & 135 & 56 & 3552 & \multirow[t]{2}{*}{0.476} \\
\hline & & 0 & 105 & 44 & 3480 & \\
\hline \multirow{2}{*}{ laborsize } & \multirow{2}{*}{$\begin{array}{l}\text { Household laborsize, if average laborsize }>2.7 \text {, of } \\
\text { laborsize }<=2.7\end{array}$} & $>2.7$ & 118 & 49 & 3528 & \multirow[t]{2}{*}{0.493} \\
\hline & & $<=2.7$ & 122 & 51 & 3600 & \\
\hline \multirow{2}{*}{ marita_statu } & \multirow{2}{*}{$\begin{array}{l}\text { Dummy variable, marital status }=1 \text { as house hold's } \\
\text { head' is married, or marital status }=0 \text { not married }\end{array}$} & 0 & 10 & 4 & 1344 & \multirow[t]{2}{*}{0.111} \\
\hline & & 1 & 230 & 96 & 3624 & \\
\hline \multirow{2}{*}{ landown } & \multirow{2}{*}{$\begin{array}{c}\text { Dummy variable, landown }=1 \text { as household head own } \\
\text { land, or landown }=0 \text { not own land }\end{array}$} & 1 & 214 & 89 & 3552 & \multirow[b]{2}{*}{0.485} \\
\hline & & 0 & 26 & 11 & 3408 & \\
\hline \multirow{2}{*}{ farmsize (ha) } & \multirow{2}{*}{$\begin{array}{c}\text { Average farm size cultivated by Household's head, } \\
\text { farmsize }<2.4 \text {, as farm less than } 2.4 \text { has or farm size } \\
\text { greater or equal farmsize }>=2.4\end{array}$} & $<2.4>=$ & 154 & 64 & 3576 & \multirow[b]{2}{*}{0.511} \\
\hline & & 2.4 & 86 & 36 & 3456 & \\
\hline \multicolumn{7}{|c|}{ 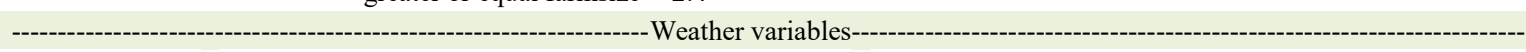 } \\
\hline \multirow[b]{2}{*}{ drought } & \multirow{2}{*}{$\begin{array}{c}\text { Dummy variable, as drought }=1 \text {, household's head has } \\
\text { experienced drought, or as drought }=0 \text {, not experienced } \\
\text { drought }\end{array}$} & 0 & 93 & 39 & 3048 & \multirow[t]{2}{*}{0.408} \\
\hline & & 1 & 147 & 61 & 3840 & \\
\hline \multirow[b]{2}{*}{ floods } & \multirow{2}{*}{$\begin{array}{l}\text { Dummy variable, floods }=1 \text {, as Household's head } \\
\text { experienced floods, or floods }=0 \text {, no floods experienced }\end{array}$} & 0 & 73 & 30 & 4104 & \multirow[t]{2}{*}{0.600} \\
\hline & & 1 & 167 & 70 & 3264 & \\
\hline & Dummy variable, aware_change=1, as house hold's & 1 & 125 & 52 & 3600 & 0.481 \\
\hline Aware change & $\begin{array}{c}\text { head is aware of weather change, or aware_change }=0 \text {, } \\
\text { not aware of the change }\end{array}$ & 0 & 115 & 48 & 3504 & \\
\hline ----------------- & 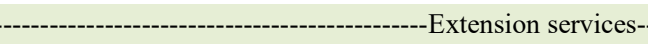 & 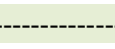 & ------ & - & 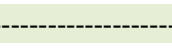 & --------- \\
\hline Ability infosed & Dummy variable, ability_infosed $=1$, as household's & 1 & 162 & 67 & 3600 & 0.467 \\
\hline Ability infosed & $\begin{array}{l}\text { head receive seeds information, or ability_intosed }=0 \text {, } \\
\text { no information }\end{array}$ & 0 & 78 & 33 & 3360 & \\
\hline & Dummy variable, like nseed $=1$, as household's head & 1 & 225 & 94 & 3600 & 0.582 \\
\hline Like nseed & like new seeds, or like__nseed=0, not like new seeds & 0 & 15 & 6 & 3480 & \\
\hline - & ---------------------------------------Production variables- & ----------- & - & -- & ------------- & ------- \\
\hline Price rice & Rice selling price, as price_rice $<607$ selling below & $<607$ & 155 & 65 & 3408 & 0.416 \\
\hline (Tshs) & $\begin{array}{c}\text { average price (Tshs), or price_rice }>=607 \text { if selling } \\
\text { equal and above average price. }\end{array}$ & $>=607$ & 85 & 35 & 3528 & \\
\hline & Major crop cultivated, major_crop $=1$ as rice been major & 1 & 208 & 87 & 3240 & 0.670 \\
\hline Major crop & $\begin{array}{c}\text { crop for the household's head, or major_crop=0 if } \\
\text { otherwise }\end{array}$ & 0 & 32 & 13 & 5352 & \\
\hline & Cost of rice seed, secost $<23000$, as seed cost incurred & $<23$ & 123 & 51 & 3696 & 0.503 \\
\hline secost & $\begin{array}{c}\text { less than Tshs } 23,000 \text {, or secost }>=23,000 \text { as cost equal } \\
\text { or above } 23,000 \text { (Tshs) }\end{array}$ & $>=23$ & 117 & 49 & 3360 & \\
\hline laborcost & $\begin{array}{l}\text { Labor cost incurred, labor cost }<=\text { Tshs } 86000 \text { as labor } \\
\text { cost equal or below Tshs } 86,000 \text {,or labor cost }>86,000\end{array}$ & $\begin{array}{c}<=86 \\
000\end{array}$ & 136 & 57 & 3672 & 0.546 \\
\hline & laborcost above Tshs 86,000 & $>86,00$ & 104 & 43 & 3336 & \\
\hline
\end{tabular}

people's life. Similarly, TAMBO \& ABDOULAYE (2012) noted that the events of continuing dry spells and heavy rainfall have caused famine to many rural families in Nigeria.

Awareness for weather variations: Significant number of farmers (52\%) acknowledged being aware of the weather variations. The awareness has helped respondents to acquire higher yields of $3600 \mathrm{Kg}$ per ha as compared to $3504 \mathrm{Kg}$ per ha acquired by their counterparts. Basically, awareness for weather variations could benefit respondents to undertake adaptation mechanisms thereby adjusting

Ciência Rural, v.49, n.11, 2019. 
planting dates, applications of adaptable seeds, planning for irrigation, etc.

\section{Crop production, extension and technology services} Ability to receive seed information: About $67 \%$ of the farmers attested to receive timely seeds information including accessibility to seeds and new seed varieties which has enabled them to secure 3600 $\mathrm{Kg}$ per ha of rice yields. In contrary to that, lack of up to date technological information reduces farmer's rice yields by ( $3360 \mathrm{Kg}$ per ha). This reveals the important of both information sharing and acceptance of new technology to farming communities. This trend seems to concur with KUMAR \& KHAN (2018) as they observed that accessible to updated information regarding to new technology, agro-meteorology was worthwhile for crops production increase in India.

Rice market price: The market price dictate the nature of production for the next growing season. For example, the previous average market price for one kilogram of rice was 607 Tanzania Shillings (TZS) (Tshs) equivalent to the US \$ 0.3 . The majority farmers $(65 \%)$ traded rice below average price; however, the analysis shows only farmers who received above average price could earn more yields. Henceforth, if the market price is decent to facilitate farmers to produce more rice and earn a higher income. Related findings reported that crop productions respond significantly to market price, and available market price could be used to forecast future crop production (XIE \& WANG, 2017).

Seed price: The average seed price for 20 kilograms of seeds was Tanzania Shillings (TZS) 23000 (US \$ 10.03), and the majority (51\%) farmers paid below the average price. Meanwhile, farmers who paid below average seeds price achieved high rice yields of $3696 \mathrm{Kg}$ per ha (Table 1). Farmers in the rural area uses local or seed from previous farm outputs which are available at relatively lower price from (800 - 1200) Tanzania Shillings (TZS) per kilogram as compared to good varieties sold by seed companies at a higher price of up 3500 Tanzania Shillings per kilogram (NBS, 2014). According to the focus group discussions it was noted that due to high seed price some farmers tend to buy and use less seeds than the recommended amount with respect to farm size. Majority farmers are reported to use a land seed ratio of ( $1 \mathrm{ha}: 8 \mathrm{~kg}$ ) instead of the recommended ( $1 \mathrm{ha}: 20 \mathrm{~kg}$ ) which end up reaping low yield. However, it is well known that use of better quality and certified seeds increase yields at the same farmers are being challenged by high seed prices, thus, calls for extension services and policy makers to have an eye look on both seeds availability and prices especially for the new varieties.

Labor cost: The average labor cost incurred was Tshs 86,000. Among the respondents, 57\% paid below the average labor cost and earned a higher yield (3672 Kg per ha). On the contrary to the rest of the farmers who received $3336 \mathrm{Kg}$ per ha. This illustrated that lesser labor cost was advantageous to farmers and is very obvious as far as farm economy is concerned. It implies that labor availability is not uniform as some farmers receive assistance from family member while others hire external labor which has implication to farmers' accrued profit. HAS (2007) pointed that if farmers could operate below the average cost of production were likely to have significant economic efficiency and yields.

Farmers' perception of weather variations with respect to rice yield

We used structured questionnaires to probe rice farmer's general views and perceptions on factors contributing to their low rice yields. Perceptions were targeting the factors which add to poor yields, and specifically on the events of weather variability. Among the weather factors discussed were rainfall, temperature, drought, and flood patterns. The obtained data were coded and analysed by Stata software; however, Garret ranking technique was used for percentage position (equation 1) calculation and ranking each factor for elucidations. The technique is chosen because using the table suggested by GARRET and WOODWORTH (1969) helps to convert percentages positions to scores and ranking is simplified. It has been employed by various researchers in psychological studies including (VISHNUVARTHANI \& SELVARAJ, 2012; DHANAVANDAN, 2016) and also recently by (ARUNKAUMAR, BALA, \& BALAJI, 2018) as is presented by equation 1 .

Percentage position $=100 *\left[R_{i j}-0.5\right] / \mathrm{Nj}$

Where $N_{j}$ is the total items ranked by the $j^{t h}$ individual (let's say farmers), $R_{i j}$ is the rank of factor $i^{\text {th }}$ for the $\mathrm{j}^{\text {th }}$ individual, and $R_{j}$ is the factor $j^{\text {th }}$.

Finally, the obtained scores for each factor are arranged in descending order and the rank is allotted for each following the most vital factors. In addition, the obtained results are compared with the empirical results from the constructed rice yield model to ascertain whether farmers' perceptions of weather variations go in line with empirical model results. Nevertheless, with the empirical model authors added independents variables including households' characteristics, technological variables, 
extension services availability, weather variables, and location specificity. Therefore, from the data analyses figures 1-2 were obtained.

\section{Influencing factors for rice yields}

Data analyses (Figure 1) have revealed that rice yield was influenced by the myriad of factors including; temperature, fertilizer, seeds, pest and diseases.

Rainfall. Among the factors, rainfall was ranked number one by the majority farmers (20.4\%) as the most important factor influencing rice yield. The claim revealed that water is a crucial input for the rice yield is obvious as rice grow well in areas with abundant water sources. This claim concurs with finding of SINGH \& SAMASTIPUR, (2014) as they pointed unreliability and high variation of rainfall which, caused decline in rice production Bihar District.

Fertilizer. It was ranked second by majority $(18 \%)$ as the factor influencing rice yield. Poor accessibility to fertilizer was reported as one of the major factors contributed to poor rice yields. These views go in line with the findings of (PRASHAR \& SHAH, 2017) as they noted that fertilizer is important to soil healthy, growth and productivity of plant. However, he contended that improper application of fertilizer could harm soil microflora and soil health.

Seeds. Seeds as among the important inputs were ranked third by the majority farmers. However, poor accessibility to quality rice seeds caused farmers to use local seeds which were easily available. MSANGYA et al. (2016) reported similar findings in Morogoro Tanzania. Msangya and his colleagues cemented that it could be the reason for the poor rice yields. Further diagnosis revealed that majority farmers lack proper knowledge for seeds estimation in relation to farm sizes.

Extension services. In addition, about $11.9 \%$ of respondents stressed on extension services as major factors influenced rice production. Extension services are very important to farmers, and play countless roles including information dissemination, training to the local community, and also consultations to farmers. Similarly, DANSO-ABBEAM, EHIAKPOR $\&$ AIDOO (2018) reported that education was helpful to farmers as could play a countless roles by adding technical and skills to farmers.

\section{Farmers' Perceptions of weather variability with respect to rice yield}

Extreme drought. Results revealed that about $70 \%$ of the respondents perceived drought to decrease their yield figure 2. It was further pointed that there has been a prolonged period of dry spell reinforced by severe sunshine and temperature. Majority farmers perceived extreme drought being behind poor yields; however, it was difficult to quantify the loss in term of Kilograms per ha.

Floods. Majority farmers $60 \%$ attested heavy rainfall as one of the problem hindering rice performances. Farmers reported that rainfall was not received on time and also not predictable. Some farmers cemented that even wet spell periods have been clearly condensed. In addition, farmers reacted by changing sowing dates from late DecemberJanuary to mid-January- early February due to capricious rainfall patterns. Similar findings were reported in Tanzania and Niger by NKUBA et al. (2016), also TAMBO \& ABDOULAYE (2012) respectively. On top of that farmers attested that floods could hinder important farm managements like weeding, fertilizer application, and flowering stage. This is consistent with the findings by (KEA et al., 2016) as they added that a significant amount of rice produced in Cambodia is damaged by floods.

High temperature. In addition, about $65 \%$ of respondents perceived high temperature

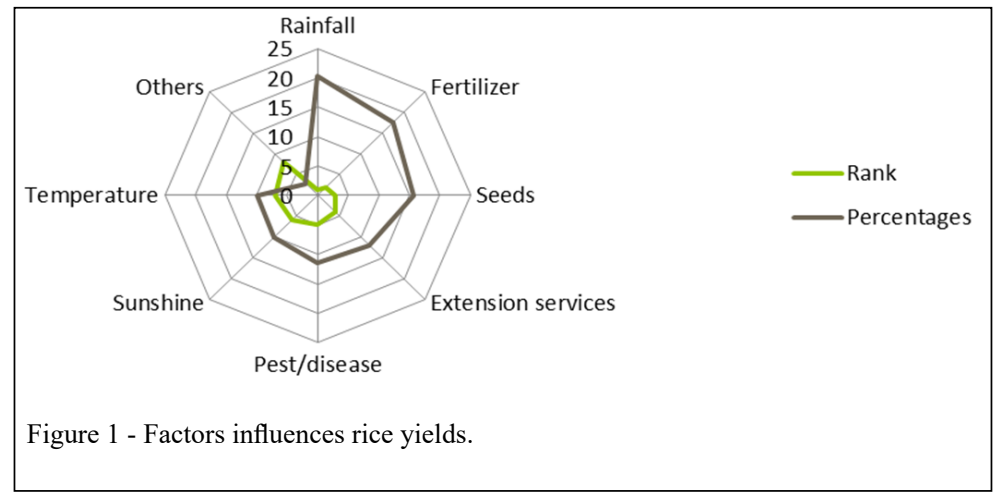

Ciência Rural, v.49, n.11, 2019. 


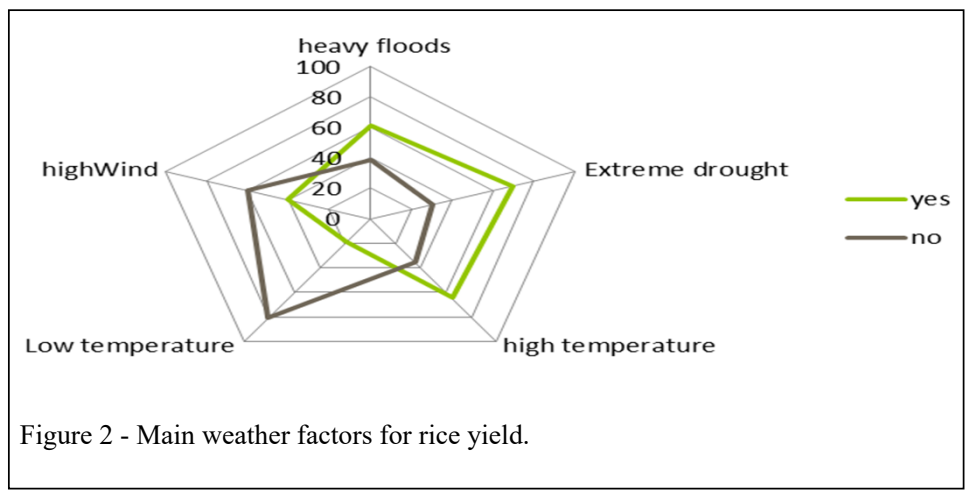

being among the factors contributing to low rice yield. Furthermore, respondents attested that high temperature is always associated with high sunshine, as well as lack of rainfall. Some respondents added that if the situation prolongs may lead to plants wilt, disease infestations, and consequently to poor rice yields. It was similarly commented that if the global temperature increase by $1{ }^{\circ} \mathrm{C}$ will reduce rice yield by $3.3 \pm 3.7 \%$ (ZHAO et al., 2017).

High-speed winds and low temperature. According to the respondents' perceptions, the least reported variables were high wind speed $(20 \%)$ and low temperature $(10 \%)$. However, majority farmers contemplated that in the near future winds could be another problem as a result of severe trees cutting, high sunshine, and the increasing population (KULYAKWAVE, XU \& YU, 2019).

\section{Empirical model and parameters estimation}

Authors constructed a linear rice production empirical model for parameters estimation. Rice yield in $\mathrm{Kg}$ per ha is denoted as $(y d)$ for producers i. Likewise to make the equation in the linear form the logarithm was introduced to the variables (Table 1) with exception of the binary variables which were termed as dummy variables (WOOLDRIDGE, 2016), and i.wn symbolizing dummy variables for location specificity (wards) in which survey was conducted as shown in equation 2. Henceforth, the model is presented by the following explicitly equations 2 and 3 .

$$
y d=\alpha_{0}+\sum_{i=1}^{n}\left(\alpha_{1-n} P_{i n}+i . w n\right)+\varepsilon_{i}
$$

Where, $y d$ is rice yield in $\mathrm{Kg}$ per ha, $\alpha_{o}$ is intercept of the regression equation, $\alpha_{1} \ldots \ldots . \alpha_{n}$ are yield coefficiency of the respective independent variables in the model, $P_{1} \ldots \ldots, P_{n}$, are the respective predictors as explained in table 1. In addition, "i. $w n$ " is a string variable designating dummy variables for the three wards representing; 2=Kajunjumele, $3=$ Ruiwa, and $4=$ Mahongole wards respectively, which are compared to $1=$ Ikolo ward from the surveyed districts, and $\varepsilon_{i}=$ error term. Others variables includes excess rainfall (excee_rains), low temperature (low_tem), strong winds (strong_winds), crop pests (crop_pest), weeds, and crop diseases (crop_diseases). More so, by expanding " $i . w n$ " from equation 2 we could obtain equation 3 which was used to estimate parameters for rice yield in Mbeya region. Therefore, the results are presented in table 2.

$$
l n Y_{d}=\beta_{0}+[\beta H]_{h=1}^{n}+[\beta W]_{w=1}^{n}+[\beta E]_{s=1}^{n}+[\beta P]_{p=1}^{n}+[\beta L]_{l=1}^{n}+\varepsilon_{i}
$$

Where the "H" represents House-hold characteristics including (education, logarithm of area to labor ratio, age, logarithm of labor size, marital status, gender, land own, major crop, and farm size), Letter "W" represent weather and perception of weather variables (awareness to change, extended floods, extended drough, logarithm of drought perception, logarithm floods perception, logarithm of excess rains, logarithm of high sunshine, logarithm of low temperature, and ln strong_winds). Letter "E" represents Extension and technology variables (Ability_infosed, logarithm of seed, like new seed variety,). Letter "P" represent Production factors (labor cost, logarithm of rice price, logarithm of crop diseases, low fertility, factor weeds, crop pest) and Letter " L" location specificity ( Iv005_2=Ikolo ward,_Iv005_2=Kajunjumele ward, _Iv005_3=Ruiwa ward, _Iv005_4=Mahongole ward) where in the model are presented as 'i.wn' dummy variable. These variables are explained in the table 2.

Results from a stepwise regression (equation 3) above produced significant variables 
Table 2 - Regression results for Yield (yd) from model (3).

\begin{tabular}{|c|c|c|c|c|c|}
\hline Yield & Definition of Variables & Coef. & Std. Err. & $\mathrm{t}$ & $\mathrm{P}>\mathrm{t}$ \\
\hline \multicolumn{6}{|c|}{ 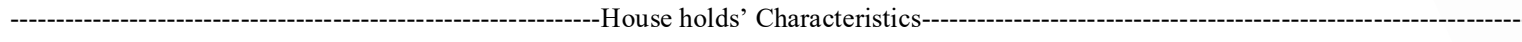 } \\
\hline educode & $\begin{array}{c}1=\text { households' education (literacy), } 0=\text { house holds' } \\
\text { education (illiteracy) }\end{array}$ & 0.142 & 0.084 & 1.690 & $0.094^{*}$ \\
\hline lnratio_a_labor & Logarithm of area to labor ratio & -0.051 & 0.117 & -0.440 & 0.664 \\
\hline age & $\begin{array}{c}1=\text { households' age is less than } 45 \text { years, } 0=\text { households' } \\
\text { age equal or greater than } 45 \text { years }\end{array}$ & -0.003 & 0.003 & -1.040 & 0.300 \\
\hline lnlaborsize & Logarithm of labor size & -0.146 & 0.146 & -1.000 & 0.320 \\
\hline maritacode & $\begin{array}{c}\text { Marital status, } 1=\text { households' head is married, } \\
0=\text { households' }\end{array}$ & 0.985 & 0.194 & 5.070 & $0.000^{* * *}$ \\
\hline gender & $1=$ households' head gender if male, $0=$ as female & 0.259 & 0.109 & 2.370 & $0.019^{* *}$ \\
\hline landown & $1=$ household's head own land, $0=$ not own land & 0.206 & 0.123 & 1.670 & $0.096^{*}$ \\
\hline majorcrpcode & $1=$ rice as major crop, $0=$ rice not a major crop & -0.351 & 0.354 & -0.990 & 0.323 \\
\hline farmsizecode & Farm size cultivated greater than 2.7 ha, or less than 2.7 ha & 0.090 & 0.140 & 0.650 & 0.520 \\
\hline \multicolumn{6}{|c|}{--- } \\
\hline aware_change & $\begin{array}{c}1=\text { households' head is aware of weather change, } 0=\text { as not } \\
\text { aware }\end{array}$ & 0.094 & 0.082 & 1.150 & 0.252 \\
\hline ext_floods & $\begin{array}{l}\text { Dummy variable, floods }=1 \text {, as experienced extreme } \\
\text { floods, or extreme floods }=0 \text {, not experienced }\end{array}$ & 0.014 & 0.091 & 0.160 & 0.874 \\
\hline ext_drough & $\begin{array}{c}\text { Dummy variable, extreme drought }=1 \text {, as experienced } \\
\text { extreme drought, or as drought }=0 \text {, not experienced } \\
\text { drought }\end{array}$ & -0.196 & 0.085 & -2.320 & $0.022^{* *}$ \\
\hline lndrought & Logarithm of respondents perception on drought & -0.075 & 0.093 & -0.810 & 0.422 \\
\hline lnfloods & Logarithm of respondents perception on excess floods & -0.010 & 0.101 & -0.100 & 0.922 \\
\hline lnexcess_rains & Logarithm of perception on excess rains & -0.171 & 0.109 & -1.570 & 0.119 \\
\hline lnhigh_sunshine & Logarithm of high sunshine as weather factor & -0.088 & 0.113 & -0.780 & 0.438 \\
\hline lnlow_temp & Logarithm of low temperature as weather factor & -0.145 & 0.121 & -1.200 & 0.233 \\
\hline lnstrong_winds & Logarithm of strong winds as weather factor & -0.132 & 0.121 & -1.090 & 0.276 \\
\hline \multicolumn{6}{|c|}{ - } \\
\hline Ability_infosed & $\begin{array}{l}1=\text { households' head receive seed information, } 0=\text { as do not } \\
\text { receive. }\end{array}$ & 0.063 & 0.082 & 0.770 & 0.444 \\
\hline lnseed_TKg & Logarithm of quantity of rice seeds & 0.165 & 0.068 & 2.430 & $0.016^{* *}$ \\
\hline like_nseed & $1=$ households' head prefer new seed, $0=$ not preferred & -0.150 & 0.141 & -1.060 & 0.291 \\
\hline \multicolumn{6}{|c|}{ 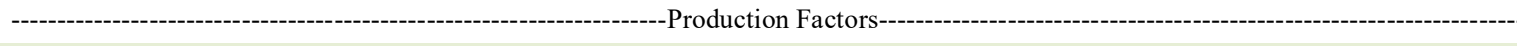 } \\
\hline lnlabor_cost2 & Logarithm of labor cost & 0.013 & 0.058 & 0.220 & 0.829 \\
\hline lnprice_rice & Logarithm of rice price & 0.447 & 0.167 & 2.680 & $0.008^{* *}$ \\
\hline lncrop_diseases & Logarithm of crop disease as factor & -0.086 & 0.097 & -0.890 & 0.377 \\
\hline lnlow_fertility & Logarithm of fertility as a factor & -0.018 & 0.096 & -0.190 & 0.851 \\
\hline lnweeds & Logarithm of weeds as factors & -0.073 & 0.129 & -0.560 & 0.575 \\
\hline lncrops_pests & Logarithm of crops pest as factor & -0.050 & 0.109 & -0.460 & 0.649 \\
\hline \multicolumn{6}{|c|}{ 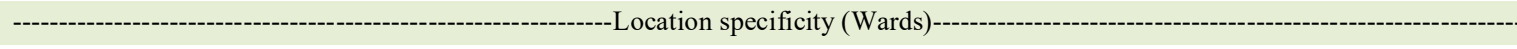 } \\
\hline _Iv005_2 & Kajunjumele & -0.040 & 0.102 & -0.390 & 0.695 \\
\hline _Iv005_3 & Ruiwa & 0.504 & 0.125 & 4.030 & $0.000^{* * *}$ \\
\hline _Iv005_4 & Mahongole & 0.431 & 0.135 & 3.190 & $0.002^{* *}$ \\
\hline cons & Constant & 4.054 & 1.856 & 2.180 & $0.030^{* *}$ \\
\hline
\end{tabular}

Note: ${ }^{* * *} \mathrm{P}<0.01,{ }^{* *} \mathrm{P}<0.05,{ }^{*} \mathrm{P}<0.1, \mathrm{R}^{2}=0.41970$, Adj $\mathrm{R}^{2}=0.3088, \mathrm{~F}=0.000$ 
which were used to construct the rice yield model as depicted in equation 4 below.

$\ln y=4.054+0.142 *$ education $+0.259 *$ gender +0.2016

* landownership - $0.196 *$ extreme drought $+0.165 *$ Inseedquantity $+0.447 *$ Inpricelag $+0.504 *$ Mahongole $+0.447 *$ Ruiwa $+\varepsilon_{i}$

Where, $y d$ is the rice yield in $\mathrm{Kg}$ per ha, $\alpha_{o}$ is an intercept of the model, $e d u=$ household head's education, marital $=$ marital status, gend $=$ gender of the household-head, land=land-ownership, inssed $=$ logarithm of quantity of seeds used per ha, exdrough $=$ experienced drought, pricelag $=$ logarithm of last season price in Tshs for $1 \mathrm{Kg}$ of rice, Mahon= Mahongole ward, Rui=Ruiwa ward, and $\varepsilon_{i}=$ error term of the regression model.

\section{RESULTS AND DISCUSSION}

The results presented in table 2 indicated that among the variables education, gender, marital status, land ownership, amount of seeds, extended drought, market price, and the respective location specificity have the positive influence on rice yield.

Household's head education. Household's education was significant at $10 \%$ probability level with rice yield. Result portrays the significance of education to farmers. Therefore, as the farmer's education increase by $1 \%$ rice yield increases by $14 \%$. Similar results were given in the study of rice production efficiency in Myanmar by (TUN \& KANG, 2015). Referring to the descriptive Table 1 , it is indicated that as households' heads acquired education from seven years to University yield increased up to $3552 \mathrm{Kg}$ per ha which was higher than $3480 \mathrm{Kg}$ per ha grossed by respondents with a low level of education. It is very obvious that the more farmers have favoured with education the more the ability to acquire and adopt different knowledge pertaining to new technology, farm management, extension services, and as well as good markets. In line to our findings, similar results were. These findings concur with what was reported in Tanzania by (NGAILO et al., 2016).

Age. Contrary to researcher expectations, respondents' age was statistically insignificant, implying that age has no influence on rice yield. A plausible reason could be due to the existence of collinearity between education and age. It is very obvious that farmers with ages from 18-45 years are more energetic and also educated as compared to those above 45 years as witnessed in Nigeria (NWAOBIALA \& ADESOPE, 2010). Descriptive results indicated that majority farmers had up to
45 years and earned a higher yield of $3696 \mathrm{Kg}$ per ha, compared to farmers aged above 45 years who obtained fewer yields of $3336 \mathrm{Kg}$ per ha. This further asserted that not all insignificant factors lack influences on rice yield as also reported in (TUN \& KANG, 2015).

Marital status. Marital status of the farmers was highly significant at $\mathrm{P}>0.00$ probability level with rice yield. Results substantiate that being a married farmer had a positive influence with rice yields. Consequently, empirically it demonstrated that being married could increase rice yield by $98 \%$. It is very obvious that married couples have challenges to work hard for the increased mouth to feed, increase labor, take care of fields, sharing knowledge and capital to influence yield. Our findings concurred with results reported in Nigeria and Tanzania (OGUNMEFUN and ACHIKE, 2015; MWATAWALA, 2016).

Gender. Household's gender was significant at $5 \%$ probability level. The analysis from description table (Table 1) verifies that female-headed household could earn higher rice yield up to $3720 \mathrm{Kg}$ per ha as compared to less yield accrued by male-headed household. Empirically it depicts that for any 1\% increase of female-headed household would increase rice yields by $26 \%$. The main reason could be the fact that in most rural areas of Tanzania specifically in Mbeya, women are more involved in agriculture activities than men. It is also known that in term of social life women are mostly the decision-maker in the region. Additionally, on the policy outlook Agricultural Sector Development (ASDP) support female-headed households with the target of uplifting more than $25 \%$ females in Mbeya region (ASHC, 2015).

Land ownership. It was significant to rice yield at $10 \%$ probability level. Therefore, an increase of $1 \%$ in land ownership by a household increases rice yield by 21 per cent. On top of that, the majority $(89 \%)$ farmers own land. In addition, it has shown in the descriptive table that farmers owning lands reaped higher rice yield ( $3552 \mathrm{Kg}$ per ha) as compared to $3408 \mathrm{Kg}$ per ha for none land ownership. The fact is families owning land have a wider chance to practice crops diversifications, and could lease land to other families. In return, the received money helps to cover some farm operations such as weeding, fertilizer and seed purchases, and also irrigation adoption. Authors' claimed is validation by the study of (PAUL, EGOR, LEONID, \& PYLE, 2015) that land ownership improves farmers' access to credits, and also propensity to invest to new technology increases.

Seed quantity. The seed quantity used by farmers was statistically significant with rice yield 
at $5 \%$ probability level. Seed use defines technology adoption and reflects farmers' economic cost point of view. From the results, it expressed that at each $1 \%$ addition in seed quantity increases rice yield by 17 per cent. Similar results were reported in Indonesia that increase in seed quantity had positively influenced yield (SILVERIUS, 2017). Accentuating further, in this research seed to area ratio was 1 ha by 8.3 kilograms which was far lesser to the recommended ratio of $(1: 20)$.

Labor size and land to labor ratio. The labor size and land to labor ratio both did not show the significant effect to rice yield; therefore, indicated that influence rice yield negatively. Firstly, it implies there is more labor than the required amount to perform farm operations. Conversely, the available labor is either engaged in other activities rather than rice farming, thus, their presence contributed less or negligible to rice yield. However, these results are different from the researcher's expectations. However, KIM et al. (2017) noted that higher number of household members could contribute more to the households' welfare if are engaged to other off-farm activities.

Extreme drought. Extreme drought event was statistically significant with rice yield at $10 \%$ probability level. Accordingly, it has a negative coefficient implying that it influenced rice yield negatively. This means that at each $1 \%$ increase in drought period reduces rice yield by 20 per cent. Similar findings were reported by (DAYTON, 2014) and also CHEN et al. (2016). At different occasions, these researchers reported that the extreme weather events including drought cases were among the factor inhibiting rice upsurge in the tropical and subtropical regions including China. Referring to figure 2 our empirical analysis goes in line with farmers' perceptions.

Previous rice price. Complementing to the aforementioned factors, the previous market price was statistically significant with rice yields. Results confirmed that the increase of previous market price by $1 \%$ enhanced rice yields by 45 per cent. It corroborated that if a farmer receives a good price for the yields could be a good signal to increase next seasons' yields of which is very obvious in the agricultural production circumstances .

Location specificity. Based on regression results, Mahongole and Ruiwa wards belonging to Mbarali district were very significant at $\mathrm{P}>0.000$ and $\mathrm{P}>0.002$ probability levels respectively. This further confirmed that rice yields do vary between locations. Possible reasons could be due to soil characteristics, weather variabilities, and management which could favour rice yields. Similar findings were reported by (HUMAYUN, 2015) and also (NGAILO, MWAKASENDO, KISANDU, \& TIPPE, 2016). Ngailo and his colleagues reported that the Mbarali rice farmers were favoured with decent weather condition including rainfall distribution and the existence of some irrigation infrastructures included the Usangu basin.

Awareness to weather change. The result indicated that the coefficient for farmers' awareness to weather variations was positive; however, it is not significant. This indicated that an increase in awareness towards weather variability has positives implication to yield increase. Being aware to changes in weather could help the farmer to plan for some adaptive measures including irrigation, droughtresistant seeds, and also altering planting period.

Extended floods. Likewise, the regression results indicated that the extended drought event was insignificant but had a positive direction towards farmer's perception. Therefore, as awareness to floods increase by $1 \%$ increases rice yield by 0.4 per cent.

Excess Rainfall. Farmer's perceived that excess and unpredictable rainfall was harmful to rice yield. According to empirical results, regardless of the fact that rainfall was not significant but having a negative coefficient indicated that at each $1 \mathrm{~mm}$ increase in rainfall reduces rice yield by $17.1 \%$.

High sunshine. The empirical result designated that; although, high sunshine was insignificant but seems to have negative effect on rice yield. Thus, an increase of 1 hour of high sunshine duration reduces rice yield by 8.8 per cent. It is very obvious that high sunshine duration during rice development including vegetative and flowering stages is detrimental to rice yield.

Low temperature and Strong wind. Regardless of the facts that they are insignificant but both have a negative influence on rice yield. So, an increase of each variable by $1 \%$ reduces rice yield by 7.3 and 5 per cent respectively. The finding is supported by local farmers as they declared highspeed winds to be a new threat for their rice.

\section{CONCLUSION}

The determination of the factors influencing rice farming and yields in the Mbeya

Ciência Rural, v.49, n.11, 2019. 
Region of Tanzania has been performed. Essentials factors and their great influences have been revealed including the households' factors education, marital status, gender, and land ownership influenced rice yield positively. Farmers are using less seed quantity but also local varieties, thus, have impaired rice yield. Additionally, farmers perceived extreme drought, floods, high temperature as their major weather factors reducing rice yield; however, they alleged events of high speed winds and low temperature as a new threats to their farming activities. Conversely, authors reported previous market rice price to have a positive influence on the next season rice yield. From the empirical analyses, some of the variables were insignificant but with impacts on rice yield. Conclusively, authors proposed to the government and other responsible stakeholders to have mutual efforts especially on developing irrigation infrastructures and advocate on extension and technological services in the study area.

\section{ACNOWLEDGEMENTS}

This article was supported by CAAS Science and Technology Innovation Project (number: CAAS-ASTRIP-2018), founded by Chinese Academy of Agricultural Sciences.

\section{BIOETHICS AND BIOSSECURITY COMMITTEE APPROVAL}

We authors of the article entitled "Households" Characteristics and Perceptions of Weather Variability on Rice Yield: Empirical Analysis of Small Scale Farmers in Tanzania" declared, for all due purposes, that the project that gave rise to the present data has not been submitted for evaluation to the Ethics Committee of the University /Research Institute " Agricultural Information Institute, Chinese Academy of Agricultural Sciences ", but we are aware of the contents of Resolution No. 466, of December 12, 2012 of the Brazilian National Health Council "http://conselho.saude.gov.br/resolucoes/2012/Reso466.pdf" if it involves humans. Thus, the authors assume full responsibility for the presented data and are available for possible questions, should they be required by the competent authorities.

\section{DECLARATION OF CONFLICT OF INTERESTS}

The authors declare no conflict of interest.

\section{AUTHORS， CONTRIBUTIONS}

All authors were involved in preparing the manuscript Conceptualization, P.D.K and X.S.; funding acquisition, X.S.; methodology, P.D.K; supervision, W.Y.; data curation and statistical analyses of the data, P.D.K; writing - original draft, P.D.K; review and editing, X.S. and W.Y. All authors critically revised the manuscript and approved of the final version.

\section{REFERENCES}

AKPAN, S. B., et al. Determinants of Decision and Participation of Rural Youth in Agricultural Production: A Case Study of Youth in Southern Region of Nigeria. Russian Journal of Agricultural and Socio-Economic Sciences, v.7. p.35-48. 2015. Available from: $<$ http://dx.doi.org/10.18551/rjoas.2015-07.05>. Accessed: Dec. 10, 2018. doi: 10.18551/rjoas.2015-07.05

ARUNKAUMAR, S. et al. A study on attitude and behaviour of the respondents towards public examination with reference to erode. International Journal of Intellectual Advancements and Research in Engineering Computations. v.6, p.6-9. 2018. Available from: <http://www.ijiarec.com/sites/default/files/ articles/IJIAREC-18-295_986-989.pdf>. Accessed: Feb. 25, 2018.

ASHC. Tanzania Country Profile -African Soil Health Consortium, 2015.1-22. Available from: $<$ https://africasoilhealth. cabi.org/materials/tanzania-country-profile-2015/>. Accessed: Nov. 06, 2018.

CHIDI, I. et al. Analysis of Socio-Economic Factors and Profitability of Rice Production among Smallscale Farmers in Ebonyi State, Journal of Agriculture and Veterinary Science, V8, p.20-27. 2015. Available from: <http://iosrjournals.org/iosrjavs/papers/vol8-issue2/Version-1/G08212027.pdf $>$. Accessed: Nov. 05, 2018.

DAYTON, L. Agribiotechnology: Blue-sky rice "The Rice Outlook." Nature. v.514, S. 52-4. 2014. Available from: $<$ https:// dx.doi.org/10.1038/514s52a>. Accessed: Dec. 26, 2018. doi: $10.1038 / 514 \mathrm{~s} 52 \mathrm{a}$

DANSO-ABBEAM, G. et al. Agricultural extension and its effects on farm productivity and income : insight from Northern Ghana. Agriculture and Food Security. vol.7, p.2-11, 2018. Available from: <http://dx.doi.org/10.1186/s40066-018-0225-x>. Accessed: May, 07, 2019. doi: 10.1186/s40066-018-0225-x

DHANAVANDAN, S. Application of garret ranking technique: practical approach. International Journal of Library and Information Studies, V.6, p.135-140. 2016. Available from: $<\mathrm{http}$ ://ijlis.org/img/2016_Vol_6_Issue_3/135-140.pdf $>$. Accessed: Nov. 30, 2018.

FEWSNET. Regional Maize Market Fundamentals-Southern Africa. Farmine for Early Warning Systems, 2016. Available from: <http://fews.net/southern-africa/special-report/ august-3-2016>. Accessed: Jul. 25, 2018.

HAS, K. A Stochastic frontier cost Function Analysis on the wheat farmers in Bangladesh. Bangladesh Journal Agricultural Economics. v.2. p.1-18. 2007. Available from: $<$ https://ideas. repec.org/a/ags/bdbjaf/200317.html>. Accessed: May, 05, 2019.

HUMAYUN, K. Impacts of climate Change on Rice Yield and Variability; an Analysis of Disaggregate Level in the Southwestern Part of Bangladesh Especially Jessore and Sathkhira Districts. Journal of Geography \& Natural Disasters, v.5. p.70-110. 2015. Available from: <http://dx.doi.org/10.4172/2167-0587.1000148>. Accessed: Nov. 26, 2018. doi:10.4172/2167-0587.1000148.

KEA, S. et al. An Analysis of Technical Efficiency for Household's Rice Production in Cambodia: A Case Study of Three Districts in Battambang Province. Global Journal of Human-Social Science, 
v.4, p.1-17. 2016. Available from: <http://dx.doi.org/10.20944/ preprints201611.0046.v1>. Accessed: Mar. 03, 2019. doi: 10.3390/ economies 4040022

KULYAKWAVE, P.D. et al. Rice farmers'perceptions and indicators for weather variability in Tanzania : what are the obstacles for in situ adaptations ?. Journal of Physics, v.1176. p.1-8, 2019. Available from: <https://dx.doi.org/10.1088/1742-6596/1176/4/042074> Accessed: May, 28, 2019. doi:10.1088/1742-6596/1176/4/042074.

KUMAR, V. et al. Importance of weather prediction for Sustainable Agriculture in Bihar, India. Archives of Agriculture and Environmental Science. vol.2. p.105-108, 2018. Available from: <https://pdfs.semanticscholar.org/3268/0c5aa6077ed3842da 3d6ee5f0e5f3b42aee0.pdf $>$. Accessed: Jan. 20, 2019.

MAKOI, J. H. J. R. PADDY (Oryza sativa L.) Production status and use of agricultural Inputs in Selected Districts of the Eastern and Southern Regions of Tanzania. Journal of Experimental Agriculture International, v.14, p.1-13. 2016. < https://dx.doi. org/10.9734/JEAI/2016/26854>. Accessed: Nov. 28, 2018. doi:10.9734/JEAI/2016/26854.

MANGO, N. et al. Climate-smart agriculture practice and its influence. Land. v.7. p.1-19. 2018. Available from: $<$ https://doi. org/10.3390/land7020049>. Accessed: Jun. 20, 2019. doi: 10.3390/ land7020049.

MKONDA, M. Y. Are Rainfall and Temperature Really Changing ? Farmer's Perceptions, Meteorological Data, and Policy Implications in the Tanzanian Semi-Arid Zone. Sustainability, v.9. p.1-16. 2017. Available from: <https://dx.doi.org/10.3390/ su9081412>. Accessed: Dec. 28, 2018. doi:10.3390/su9081412.

MKONDA, M. Y. et al. Yields of the major food crops: Implications to food security and policy in Tanzania's semi-arid agro-ecological zone. Sustainability (Switzerland), v.9. p.1-5. 2017. Available: $<$ https://dx.doi.org/10.3390/su9081490>. Accessed: Nov. 28 , 2018. doi. $10.3390 / \mathrm{su} 9081490$.

MOHANTY, S. et al. Rice and climate change : significance for food security and vulnerability. International Rice Research Institute Discussion Paper, v.49, p.1-8. 2013. Available from: $<$ https://pdfs.semanticscholar.org/b419/4a87638354dd357241dbb d892db86afac279.pdf? ga=2.17391419.349759294.1567432041929053467.1546349257>. Accessed: Dec. 01, 2018

MSANGYA, B. et al. Challenges for Small-Scale Rice Farmer. International Journal of Scientific Research and Innovative Technology. A Case Study of Ulanga District-, v.3, p.65-72. 2016. Available from: $<$ https://docplayer.net/amp/38987054>. Accessed: Nov. 06, 2018

MTONGORI, H. I. et al. Impacts of climate and Farming Management on Maize Yield Southern Tanzania. Crop, African Society, Science, v.23, p.399-417. 2015. Available from: $<$ http:// dx.doi.org/10.4314/acsj.v23i4.9>. Accessed: Jul. 25, 2018. doi: 10.4314/acsj.v23i4.9

MUGULA, V. et al. Farmer's perceptions on climate change impacts in different rice production systems in Morogoro Tanzania. International Journal of Scientific and Research Publications, v.6, p.334-340. 2019. Available from: <http://www.ijsrp.org/ research-paper-0216/ijsrp-p5053.pdf>. Accessed: Mar. 15, 2018

MUTHAYYA, S. et al. An overview of Global Rice Production, Supply, Trade, and Consumption. Annals of the New York
Academy Of Sciences, s.1324. p.7-14. 2014. Available from: $<$ https://dx.doi.org/10.1111/nyas.12540>. Accessed: Nov. 05, 2018. doi: 10.1111/nyas. 12540 .

MWATAWALA, H. Paddy Production in Southern Highlands of Tanzania: Contribution to Household Income and Challenges Faced by Paddy Farmers in Mbarali District. Scholars Journal of Agriculture and Veterinary Science, v.3, p.262-269. 2016. Available from: <http://saspjournals. com/wp-content/uploads/2016/05/SJAVS-33262-269.pdf $>$. Accessed: May, 20, 2019.

NATIONAL BUREAU OF STATISTICS (NBS). The 2012 population and housing census: basic demographic and socioeconomic profile; Key Findings. Dar es Salaam, Tanzania: NBS and OCGS. 2014. Available from: <tanzania.countrystat.org> . Accessed: May. 30, 2019

NGAILO, J. A. et al. Rice Farming in the Southern Highlands of Tanzania: Management Practices, Socio-Economic Roles and Production Constraints. European Journal of Research in Social Sciences, v.24. p.73-87. 2016. Available from: <www. idpublications.org>. Accessed: Jul. 10, 2018.

NKUBA, J. et al. Rice Value Chain Analysis in Tanzania: Identification of Constraints, Opportunities and Upgrading Strategies of the four countries that participated in the Eastern Africa Agricultural Research Project (EAAPP). African Crop Science Journal, v.24, p.73-87. 2016. Available from: <https:// dx.doi.org/10.4314/acsj.v24i1.8S>. Accessed: Nov. 06, 2018. doi:10.4314/acsj.v24i1.8S.

NWAOBIALA, C. et al. Economic analysis of small holder rice production systems on Ebonyi State South East, Nigeria. Russian Journal of Agricultural and Socio-Economic Sciences, v.11, p.3-10. 2010. Available from: <https://ideas.repec.org/a/ scn/031261/14500350.html>. Accessed: Nov. 29, 2018.

Ogunmefun, E. S. et al. Socio-economic characteristics of rural farmers and problems associated with the use of informal insurance measures in odogbolu local government area, Ogun State, Nigeria. Russian Journal of Agricultural and Socio-Economic Sciences, vol.2. p.1-119. 2015. Available from: $<$ https://dx.doi. org/10.18551/rjoas.2015-02.01>. Accessed: Nov. 29, 2018. doi: $10.18551 /$ rjoas.2015-02.01

OTEKHILE, C. A. et al. The Socio-economic characteristics of rural farmers and their net income in Ojo and Badagry Local Government areas of Lagos State, Nigeria. Acta Universitatis Agriculturae et Silviculturae Mendelianae Brunensis. v,65. p.2037-2043. 2017. Available from: <https://dx.doi.org/10.11118/ actaun201765062037>.Accessed: May, 2, 2019. doi: 10.11118 actaun 201765062037

PAUL, C. D. et al. Costs and benefits of land ownership: The Case of Russian Firms. HSE Working papers, WP BRP 107/EC/2015 National Research University Higher School of Economics. 2015. Available From: <https://ideas.repec.org/p/hig/wpaper/107ec-2015.html>. Accessed: Nov. 29, 2018.

PRASHAR, P. et al. Impact of fertilizers and pesticides on soil microflora in agriculture. Sustainable Agriculture Reviews, v.19. p.331-361. 2017. Available from: $<$ https://dx.doi.org/10.1007/9783-319-26777-7 8>. Accessed: May, 7, 2019. doi:10.1007/978-3$319-26777-7 \quad 8$

Ciência Rural, v.49, n.11, 2019. 
ROWHANI, P. et al. Climate variability and crop production in Tanzania. Agricultural and Forest Meteorology, v.151, p.449-460. 2011. Available from: <https://dx.doi.org/10.1016/j. agrformet.2010.12.002>. Accessed: Apr. 14, 2019. doi: 10.1016/j. agrformet.2010.12.002.

SILVERIUS, L. Several Factors that Influence Household Economic Decisions of Rice Farmers in Indonesia. Russian Journal of Agricultural and Socio-Economic Sciences, v.1, p.1-14. 2017. Available from: <https://dx.doi.org/10.18551/ rjoas.2017-01.17>. Accessed: Nov. 05, 2018. doi.org/10.18551/ rjoas.2017-01.17.

SINGH, K. M. et al. Impact of rainfall on agricultural production in Bihar: A Zone-Wise analysis impact of rainfall on agricultural production in Bihar: A Zone-Wise analysis. Environment and Ecology, v.4. p.1571-1576. 2014. Available from: <https://ssrn. com/abstract $=2464398>$. Accessed: May, 07, 2019.

TAMBO, J. A.; ABDOULAYE, T. Climate change and agricultural technology adoption: The case of drought tolerant maize in rural Nigeria. Mitigation and Adaptation Strategies for Global Change, v.17. p.277-292. 2012. Available from: <https://dx.doi org/10.1007/s11027-011-9325-7>. Accessed: Sep. 17, 2018. doi: 10.1007/s11027-011-9325-7.

THERKILDSEN, O. Policy making and implementation in agriculture: Tanzania's push for irrigated rice. DIIS Working Paper 2011:26. 2011. Available from: <http://hdl.handle. net/10419/122235>. Accessed: Nov. 06, 2018.

TIGCHELAAR, M. et al. Future warming increases probability of globally synchronized maize production shocks, v.115, p.6644-6649. 2018. PNAS. Available from: <https://dx.doi. org/10.1073/pnas.1718031115. Accessed: Jul. 25, 2018. doi:10.1073/pnas.1718031115.
TSEGA, M. et al. Socioeconomic characteristics of smallholder rice production in Ethiopia. Ethiopian Institute of Agricultural Research. Addis Ababa-Ethiopia. 2013. Available from. <http:// www.eiar.gov.et>. Accessed: May, 05, 2019.

TUN, Y. et al. An Analysis on the Factors Affecting Rice Production. Journal of East Asian Economic Integration, v.19, p.180-183. 2015. Available from: <http://dx.doi.org/10.11644/ KIEP.JEAI.2015.19.2.295>. Accessed: Nov. 29, 2018.doi: 10.11644/KIEP.JEAI.2015.19.2.295.

VAN ITTERSUM, M. K. et al. Can sub-Saharan Africa feed itself? Proceedings of the National Academy of Sciences. PNAS, v.113, p.14964-14969.2016. Available from: < http://www.pnas. org/cgi/doi/10.1073/pnas.1610359113>. Accessed: Jul. 11, 2018. doi:10.1073/pnas.1610359113.

VISHNUVARTHANI, S. et al. Factors Influencing the Passengers to Select Train Travel : A Study in Salem Division of Southern Railway. International Journal of Scientific and Research Publications, v.2, p.81-84. 2012. Available: < http://www.ijsrp.org/researchpaper-1012/ijsrp-p1056.pdf > . Accessed: Nov. 30, 2018.

WOOLDRIDGE, J. M. Introductory Econometrics. A modern Approach (sixth) Edition, Michigan State University, Australia. p.61-62. 2016. Available from: <https://economics.ut.ac.ir/ documents/3030266/14100645/Jeffrey_M._Wooldridge Introductory_Econometrics_A_Modern_Approach_2012.pdf $>$. Accessed: Dec. 07, 2018.

ZHAO, C. et al. Temperature increase reduces global yields of major crops in four independent estimates. PNAS,v.114,p.1-6.2017. Available from: <https://doi.org/10.1073/pnas.1701762114>. Accessed: Dec. 01, 2018.doi: 10.1073/pnas.1701762114. 